\title{
USING SIMULATION METHODS TO IMPROVE STUDENT LEARNING
}

\author{
Dr. Dwi Wulandari ${ }^{*}$ and Bagus Shandy Narmaditya ${ }^{2}$ \\ ${ }^{1,2}$ Faculty of Economics, Universitas Negeri Malang
}

\begin{abstract}
A basic understanding which is owned by the students come from a variety of experiences and activities that will form the knowledge. Less understanding of the capital market is usually caused by the discussion that is only based on the textbook. This research aims to improve the activity and the understanding of capital markets by applying simulation method. This research is classroom action research. The draft of the study involved lecturer observer and student research on the subject. This research was conducted in the course of Banking and Finance. Cycle stages of classroom action research are planning, action, observation, and reflection. The result of this study, 1) Implementation of simulation methods can increase student activity. From $60 \%$ activities in the first cycle to $92 \%$ activities in the second cycle, 2) The understanding of students has increased significantly from the previous learning, From $76 \%$ in the first cycle and $85 \%$ in the second cycle. This proves that the application of simulation method can improve the activities and understanding of the capital market because this method made the students more active and more engaged in learning activities.
\end{abstract}

Keywords: simulation method, learning activities, capital market

\section{INTRODUCTION}

Capital Markets offers a new alternative for businesses to obtain funding source for its business, in addition to adding new investors to invest outside the banking sector. Capital markets serve as a media for investment for people who want to invest in the long term or short term. The capital market has a major role in the economy of a country because it has two functions, economic and financial functions. The capital market is said to have a function in the market economy as it provides the facility or the vehicle that brought the two interests, namely those who have excess funds (investors) and those who need the funds (issuer). With the capital markets, the parties who have excess funds may invest those funds in the hope of reward (return) in the form of dividends while the issuer (in this case) can use the funds for investment purposes without having to wait for the availability of funds from the company's operations. The capital market is said to have a financial function, because the capital market provides the possibility and the opportunity to earn rewards (return) for the owner of the funds, according to the characteristics of the selected investments.
At the macro level of the economy, the capital market serves as a means of redistributing income. The public can enjoy the benefits of the company although they are not founders or managers, is to buy a company's stock. So that the company's profits can be enjoyed by the general public with the help of the capital. For market companies, capital markets also provide a major advantage, which is to expand its business (expansion) by using the proceeds from the sale of shares in this market without having a debt to the bank which the interest is quite large, with complex requirements.

Given the importance of the capital market in the economy as well as for the individual it is very important also to understand the capital market. This is consistent with the purpose of the Indonesia Stock Exchange (IDX) to increase the number of local investors is to conduct socialization and education of Capital Market to the public, because public's understanding of the capital market is still uneven and there are still many who do not understand how to invest in stock market. Socialization and

Corresponding Author: *Wulan501@yahoo.com 
education programs aimed at housewives, professionals, retirees, students, and other community groups, through a variety of outreach programs and education are diverse.

To make people understand about the capital market can be done through various efforts including a seminar on capital market by Indonesian Stock Exchange and through learning in the classroom. One of the subjects that include capital market in the learning is Monetary Economics. Surely the lesson activities in the classroom have several advantages such as longer time owned, students also have the ability to think critically. In the practice and learning about the capital market, there are various problems and obstacles so that the level of understanding of the capital market is still lacking, it is will affect the interest of the desire to support the capital market in Indonesia.

Various obstacles and problems encountered during the observation are limited understanding of the students know the concepts contained in the textbooks, learning models in one direction so that the activity level of students lacking. This is in accordance with Kunandar (2010) stated that student activity is the involvement of students in the form of attitudes, thoughts, attention, and student activity in learning activities to support the success of the learning process and to benefit from these activities. Role-play exercises and simulations are just part of a larger body of teaching strategies labeled as active learning techniques, techniques that ask students to participate in constructing their own knowledge (Shaw, 2010).

In addition, conditions that exist in the field of understanding the concept of capital market is still considered difficult because a lot of terms that are less familiar to the students. Giving an understanding of how to assess stock, the approach is still difficult to grasp (fundamental and technical approach) if the student does not do this directly approach the concept will be more difficult to understand. Based on these problems, it is through this class action research and the researchers intend to seek alternative solutions.

Thus the simulation learning method is considered as one of the alternative methods of learning in order understand the capital markets. Blank (1985) stated that a simulation is an operating model which demonstrates the structure of a system. Simulations designed as learning tools are those that provide participants with a new or improved understanding of the system which has been modeled. Hamalik (2005) says that simulation exercises are demanding practical skills that will be implemented in real life situations. Jones (2003) have suggested that while simulations may increase student engagement, students can often struggle to understand what they are learning in these interactive contexts. More active method is believed to be better than more passive methods at developing deep learning, and facilitating the development of more innovative and creative thinkers (Dorn 1989; Brock and Cameron 1999).

In general, the positive utilities attributed to roleplays and simulations within the literature can be summed up in three broad categories: depth of learning, student engagement, transferable skills development. Depth and Breadth of Learning: The first group of benefits attributed to simulations relates to the suggested improvements in overall student learning. Student Engagement: The second broad group of benefits ascribed to simulations within the literature relates to positive effect that the method produces in terms of student engagement. Transferable Skills Development: The final broad area of support for simulation-based teaching relates to a specific skill set developed through this method that are not generally well cultivated through more traditional methods (Clayton and Gizelis, 2005).

The goal of the simulation methods which are: (1) train certain skills is both professional and everyday life, (2) gain an understanding of a concept or principle, (3) practice solving problems, (4) improve learning activity, (5) improve the students' learning motivation, (6) train students to establish cooperation, creativity and (7) train students to develop an attitude of tolerance.

In any form of simulation will take place the following matters: (1) the player plays that represent the real world, and also make decisions in reacting to their assessments of the setting that they find themselves, (2) they are experiencing acts of imitation associated with their decisions and their general appearance, (3) they monitor the results of their respective activities, and are directed to reflect on the relationship between their own decisions and the 
consequences of the end of the show a combination of various actions.

\section{RESEARCH METHODS}

This study is a class action is a form of research that is reflective by using specific actions in practice. This classroom action research conducted with a view to increasing the actions in the implementation of learning and solving problems that arise in it. Classroom action research is also one of the efforts to repair and improve the learning activities as well as to overcome the difficulties in the learning process experienced by students. Classroom action research was conducted in two cycles to improve student understanding and activities of the capital market through simulation method. Each cycle includes four stages: planning, action/observation, evaluation, and reflection.

This action research conducted in the second semester of 2014/2015 for subjects Monetary Economics. This study will involve as many as forty students of the fifth semester. The parties involved in this research are a principal investigator and professor as well as the perpetrators of acts, two observers (lecturers), forty students as subject learners. Data collection techniques that will be used in this research is observation, interview, documentation, and questionnaire. For instruments used to adopt innovative teaching of the Council for Economic Education (CEE, 2009).

The data will be obtained from this research is qualitative data and quantitative data as supporters. Data analysis was performed according to the characteristics of the data collected. From the data collected classified and categorized in a systematic way and according to its characteristics. While quantitative data were analyzed with the descriptive quantitative method. These findings will be used to carry out further actions. The validity of the data in research in conducted with triangulation techniques. Moleong (2005) says triangulation is a technique that utilizes data validity checking things outside the data for the purpose of checking or as a comparison data. This study uses a triangulation of sources and methods. Indicators of successful action is the good response from the students, who marked increase in student activities, and student understanding of the capital markets.

\section{RESULT AND DISCUSSION}

\section{Implementation of the Measurement the First Cycle}

The first step in this research is the planning of activities. Planning activities include the manufacture of teaching plan, Worksheet Group, Preparing questions and answer key test, prepare observation sheets, and preparing interview guides. During the implementation phase of this learning action, lecturer implemented simulation teaching methods. The simulation will ask students to choose to make an investment with a given amount of capital. The capital is the same for each group. The main purpose of the game is the highest return for each team. The return of each team will be compared and the winner is a team with the highest return. The student is given the option to choose between five companies and make a portfolio of investment. The result will depend on the stock price that is given by the lecturer after reading stories of what happened to the company during the years. Learning is done based on teaching plan that previously been prepared by the researchers, is to market the material of capital market.

The conduct of the first meeting includes the following steps

1. Lecturer open lessons with greetings, checking on students' expression then conduct a brief presentation and talk about basic competencies to be achieved.

2. Lecturer conveys rules for simulating the capital market by providing an explanation of these companies to be invested in and what are the prospects of each company that will be taken into consideration for investment.

3. Researchers assisted fellow observer to divide students into groups

4. The group division is considering the heterogenity of students by gender and academic achievement. Students are divided into groups. One group consists of five students. One class consists of eight groups. 
5. Students work in groups each to make analysis to determine the choice of where to invest their money.

6. After analyzing and discussing what and how decisions are taken, the results of the election in which the funds invested in the written worksheet group that has been prepared.

7. After all the group decided to invest, the lecturer read the company's development from the $\mathrm{A}$ to the next 10 years, about what happens to the company, whether the company for 10 years have profit, loss or break even and whether the company distributes all dividends, partially or not at all.

8. Once the simulation is complete the next stage of evaluation by using worksheets groups that have been given and to know the work of students.

The results of the observations made to increase the students' understanding and student activities can be seen at every meeting and measured per cycle. From student's understanding of the capital market showed a significant improvement after using the simulation of both the category average number of $76 \%$. As for student activities, in general can be concluded that the level of activity some students still feel less confident to be active in the simulation. In the average percentage is $60 \%$. Some students are passive though lecturers and researchers have long to give some kind of change. So it can be seen in participation activities, give opinions still low it is associated with a given problem. Student Activity Indicator can be seen from the increase in student collaboration, activeness of asking, active work on the problems, the attention of students while in class. This more active method is believed to be better than more passive methods at developing deep learning, and facilitating the development of more innovative and creative thinkers (Dorn 1989; Brock and Cameron 1999).

\section{Some of the flaws found in the first cycle are:}

The time of each round is 15 minutes. Some students rather difficult to divide tasks and assign decision
1. Some students could not perform simple calculations manually so as to make the buying process and the determination of the stock to long.

2. The debates among students occur in quite a long time because some have a character that is very cautious and some are willing to take risks.

3. Calculation of the sale of shares sometimes must be guided by the lecturers, because of the lack of student understanding of the rules of the game

4. Reading a long stock prospectus to make students tend to get bored and confused.

Based on the analysis and reflection of the first cycle by looking from the level of student activity is still low on the observation sheet and interviews result conducted in the first cycle, so there is a need to be an improvement. Follow up to increase the activity of students between activities: every purchase decision should be accompanied by an argument with this will spur students' level of activity. Students are welcome to comment purchasing decisions of other groups. Students who can read stock trading patterns that occur in class will be awarded points. This will certainly spur the desire and the courage to argue that overall will increase the activity of understanding regarding the learning material. For capital market efforts that can be done is by giving instruction and understanding the terms first, then the new students are given a prospectus on the condition of the company to read.

\section{Implementation of the Measurement of the Second Cycle}

In general, the implementation of the second cycle is similar to the first cycle, includes lesson plans, preparing worksheets group, prepare the questions and key. The implementation of the second cycle as follows.

1. Lecturer opens the lesson with the greeting, check the presence of students then conduct a brief presentation and convey basic competencies to be achieved. 
2. Lecturer convey rules for simulating the capital market by providing an explanation of these companies are to be used and what are the prospects of each company that will be taken into consideration for investment.

3. Researchers assisted fellow observer to divide students into groups

4. The group divisions were paying attention to the heterogenity of students by gender and academic achievement. Students are divided into eight groups. One group consists of five students. Given the experience of the first cycle, the division of the group is somewhat more considerable to the position so that each group will be participating in the discussion.

5. Students work in groups to make analysis to determine the choice of where to invest their money in this stage to determine the long-term investment.

6. After analyzing and discussing what and how decisions are taken, the results of the election in which the funds invested in the written worksheet group that has been prepared.

7. After the simulation is completed the next stage of evaluation by using worksheets groups that have been given and to know the work of students.

The results of the observations made to the understanding of the students and student activity can be measured or seen in every cycle. Based on two meetings, student understanding of the capital market showed a significant increase from cycle 1 to cycle 2 that is equal to $85 \%$. This increase can be seen from the understanding of the concept and the views from the decision making the final tally score tradeoffs in determining choices of stocks. While for student activities that can be shown visible improvement demonstrated the cooperation of students, liveliness asked, active work on the problems, the attention of students when classes are already well, It can be seen in this second cycle based on aspects or indicators were observed, it appears that the level of student activities mostly in the good category as many as 24 students (60\%). Meanwhile, $10(25 \%)$ of students are very high category. In general, it can be concluded that the level of activity of students in the second cycle students have seen some students are already active in the simulation. At the liveliness indicators lecturers ask and answer questions. Students have also been seen increasingly enthusiastic in activities related to the determination of shares and joint decision. However, there are still some students who did not seem actively discussing in groups. Not seen students chatted with friends outside the learning topics.

\section{CONCLUSION}

Based on the results of research and discussion undertaken on before, in general, it can be concluded that the application of learning methods of simulation can increase the activity of students in the learning and understanding of the capital markets. Increased activity and student understanding are because the simulation method provides an opportunity for students to think, argue, discuss and explore themselves in the buying and selling of shares so that it would have an impact on student activities. As well as an understanding of the capital markets can be seen in the simulation students participate actively and directly in activities of buying and selling stocks where previously in the lecture more use concepts that exist in books without direct experience of simulated stock trading with a variety of conditions that led to a wise decision. The understanding and the student activity showed there was an increase from cycle 1 to cycle 2 . From the above results and discussion, the suggestions from the researcher, namely: 1) learning model simulation can be used as a learning model of democratic innovation that can be applied in the classroom to enhance students' learning activities by providing clear instructions and coherent from beginning to end. 2) For those who want to further examine related simulation methods need to be developed to add other aspects that are not investigated in this study.

\section{REFERENCES}

Blank, S.C. 1985. Effectiveness of Role Playing, Case Studies, and Simulation Games in Teaching Agricultural Economics. http://ageconsearch. umn. edu/bitstream/32523/1/10010055.pdf 
Brock, K, L., Cameron, B. J. 1999. 'Enlivening Political Science Courses with Kolb's Learning Preference Model' Political Science and Politics, Vol. 32, No.2, 1999, pp. 251-256.

Council For Economic Education. 2009. Agenda and Materials Training Program Coaches. Council on Economic Education (DPE / NCEE): New York.

Dorn, D.S., 1989. 'Simulation Games: One More Tool on the Pedagogical Shelf' Teaching Sociology, Vol.17, No.1, 1989, pp. 1-18.

Govinda Clayton, Theodora-Ismene Gizelis. 2005. Learning through Simulation or Simulated Learning? An Investigation into the Effectiveness of Simulations as a Teaching Tool in Higher Education 2005,4(5):1- 25.
Hamalik, Oemar. (2005). Proses Belajar Mengajar Jakarta: Bumi Aksara

Jones, K., 2003. Simulations: A handbook for teachers and trainers (Gilford, Kogan Page, 2003).

Kunandar. 2010. Teachers Implementation Unit Level Curriculum (SBC) and Success in Teacher Certification. Jakarta: PT. Raja Grafindo Persada.

Moleong, Lexy.J.. 2005. Qualitative Research Methodology. Bandung: PT Youth Rosdakarya

Shaw, Carolyn M. 2010. "Designing and Using Simulations and Role-Play Exercises." The International Studies Encyclopedia. Denemark, Robert A. Blackwell Publication 